\title{
The elementary foundations of formal analysis ${ }^{1}$
}

\section{Boris Yarkho}

\section{The composition of literary form}

\section{$\S 1 .-$ The concept of form}

These days a lot has been said about literary form, and not without reason. On the contrary, I think that most of those working in this field are on the right track, trying to find and identify what the history and theory of literature should in fact study.

Therefore, if I venture to write a few lines on these issues, it is not because I want to argue with anyone, but only because I would like to introduce some clarity and simplicity to the question of the composition and the nature of literary form, and, perhaps, thus somehow facilitate practical work with literary texts.

First and foremost, [we need] a definition of artistic form:

The totality of the elements of a literary work that are capable of affecting aesthetic feeling (either positively or negatively, it makes no difference) is what we call "form".

Any definition must in the end rely on something indefinable. The aesthetic emotion is just as indefinable as any other emotion, i.e. anger, grief, disappointment, etc., while at the same time, everyone knows what it is.

Everyone also knows that not a single phenomenon of the external world is able to directly stimulate aesthetic feeling, that it must be preceded by certain sensory and cognitive acts.

\footnotetext{
* I emphasize this because I want the reader to look at the present article from this practical point of view, i.e. to ask himself the following question: is it pragmatic to work with material using the proposed scheme or not?

** The third part of G[ustav] G. Shpet's Esteticheskie fragmenty [Aesthetic Fragments, Petersburg, 1923] was published only after this article had already been written. On pages 8 and 9 of this book I read with pleasure his exposition of an almost identical doctrine. This saves me the trouble of giving a detailed account of my views on aesthetic (positive or negative, i.e. beautiful or unbeautiful) and non-aesthetic (i.e. irrelevant from the standpoint of beauty) verbal objects. See also: B. Yarkho, "Granitsy nauchnogo literaturovedenija" ["The limits of the scientific study of literature"] ([the journal] Iskusstvo [Art, 1925] II, pp. 48 and 49).
} 
Hence two questions: (a) about the stimuli contained in the literary work itself, and (b) about the mediating psychic acts, or intermediaries contained in the mind of the perceiver.

I must say right away that a literary historian and a literary theorist should be interested only in the former question, i.e. the stimuli themselves (the facts of the external world).

The totality of the stimuli is form, which is the subject matter of literary studies.

The totality of the intermediaries is the perception of the literary work, which is the subject matter of psychology.

If we now speak about intermediaries, it is only to understand the actions of various stimuli and to group them.

\section{$\S 2$. - The division of the formal types according to psychic intermediaries}

The fact is that failure to take intermediaries into account sometimes causes confusion in the delineation of the types of literary forms themselves.

Let me cite an example. We define a literary "image" as follows:

Images in a literary work are those meanings of words that evoke an idea of sensory perception.

Walzel (Problema formy $v$ poezii [The Problem of Form in Poetry], tr. by [M. L.] Gurfinkel', Petersburg, 1923, p. 30), ${ }^{2}$ who provides a nearly identical definition of the image, adds: "This includes such elements of poetic imagery as similes, metaphors, and other related phenomena..."

Obviously, the facts of iconology (the study of images and motifs) and the facts of style are confused here. Indeed, does the essence of the figures mentioned above lie in the sensory associations evoked by them? Do metaphors and comparisons differ in the images they elicit? For example:

Vossel sokol na dobra konja.

[Russian: 'The falcon mounted the good steed'.]

On, kak sokol, vossel na dobra konja.

[Russian: 'He, like a falcon, mounted the good steed.]

In both cases the reader imagines a man whose rapid movements and other features make him similar to a falcon. The difference is not in the image, but in the way the concepts are connected logically. 
This confusion of facts, to which we object, comes from the circumstance that some figures, such as all tropes (metaphor, metonymy, synecdoche, irony, litotes) as well as bipartite figures (simile, antithesis, oxymoron, and so on), are able to elicit new images in the process of their formation. For example:

calix non mellis, sed fellis.

[Latin: 'a chalice not of honey, but of bile'.]

The image of "honey" is added here as a contrast in order to reinforce the main image of "bile." All of this is emphasized by the figure known as Schema kat" arsin kai thesin. ${ }^{3}$

But now we shall see that all this can be done without images. For example:

"It is not reasoning that is needed here, but intuition".

The figuration here is the same, and the aesthetic effect of the sentence is based on it alone. No image - an iconic void.

It seems clear now: stylistic forms are based not on images, but on concepts. In practice this implies that metaphor, metonymy etc. should be regarded - and I most decidedly insist on this - separately from the images they contain in order to avoid methodological confusion.*

The vast majority of stylistic figures have nothing to do with sensory associations. Here belong all the so-called grammatical (or, more precisely, morphological) figures, including all kinds of enallage ${ }^{4}$, such as, for example, heterarhithmon": "the enemy is powerful" (instead of "the enemies are powerful"). The reader, of course, imagines a multitude of enemies, but the usage of the singular imparts to this image a purely abstract concept of totality.

Syntactic figures based on the position of words in a sentence, such as parallelism, chiasmus and so on, are of the same nature.

* We would willingly call them "real" figures, in contrast to "purely modal" figures, which change only the mode of perception.

** Now we shall use an elementary schema for purposes of illustration:

\begin{tabular}{l|l|l|}
\cline { 2 - 3 } \multicolumn{1}{c|}{} & \multicolumn{1}{c|}{ metaphor } & \multicolumn{1}{c|}{ simile } \\
\cline { 2 - 3 } A rose & $\begin{array}{l}\text { Tsvetushchuju rozu geroj poljubil. } \\
\text { [Russian: 'The hero fell in love with a blooming rose'. }]\end{array}$ & $\begin{array}{l}\text { Anna rozoju tsvela. } \\
\text { [Russian: 'Anna was blooming like a rose'. }\end{array}$ \\
\hline A deer & $\begin{array}{l}\text { O, lan', vnemli ljubvi moej. } \\
\text { [Russian: 'O, deer, listen to my love'. }]\end{array}$ & $\begin{array}{l}\text { O, deva, bystraja, kak lan'... } \\
\text { [Russian: 'O, maiden, fast like a deer.'] }\end{array}$ \\
\cline { 2 - 3 }
\end{tabular}

The horizontal row demonstrates the identity of images (the subject matter of iconology), the vertical row demonstrates the identity of figures (the subject matter of stylistics). 
Exodus $15: 10$. Thou didst blow with thy wind, the sea

parallelism

15:12. Thou stretchedst out thy right hand, the earth swallowed them.

(prope

aequatum $)^{6}$

In order to understand the similarities between the grammatical forms and their order a sophisticated logical act is needed, without which the figure will not produce any aesthetic effect.

In general, regardless of the fact that some stylistic phenomena are often related to phenomena of a different order (see below, $\$ \$ 4$ and 5), they are all united by the following feature: instead of changing the image they change the logical mode of its perception. On the basis of this feature they can be identified as a separate group, which should not on any account be mixed with the iconic elements of a work.

Since the aesthetic effect of the figures cannot be doubted, and this action cannot take place without a logical act, we have to recognize the aesthetic potency of mental acts, the aesthetics of logic.

Another lesson follows from consideration of the theory of [Ernst] Elster (Prinzipien der Literaturwissenschaft, Halle, 1911, p. $11 \mathrm{ff}$ ), which unifies under the whole of "style" not only the elements of stylistics proper (see below), but also metrics."

It is evident, however, that phonic elements have nothing to do in principle with the meaning of a word and with logical perception in general. Rhyme, alliteration and other euphonic forms affect auditory sensation, which can directly stimulate aesthetic feeling. Consider the following verses of the troubadour Aimeric de Belenoi:

Al prim pres dels breus jorns braus

quan branda'ls bruelhs l'aura brava...

[Provençal: 'At the first approach of the brief, harsh day,

when the harsh wind shakes the wood...']

Not only the meanings of the alliterating words, but even their number and the temporal distance between them are irrelevant for the phonic impression here. All metric forms, both simple and complex (see $₫ 5$ a below), are unified

* The same division was proposed by Prof. V[iktor] M. Zhirmunsky [in his "Zadachi poetiki" ("The Tasks of Poetics")], [the journal] Nachala [The Beginnings], 1921, no. 1. 
by the fact that they must affect auditory sensation. They are placed in the same group on the basis of this common feature.

These theses lead to the following conclusions:

a) Images, stylistic forms, and metrics affect aesthetic feeling and therefore comprise part of literary form, but they do so in three principally different ways.

b) They use psychic intermediaries in the following way:

a) All images operate by means of sensory associations.

$\beta$ ) All stylistic elements operate by means of logical acts.

$\gamma$ ) All phonic elements operate by means of auditory sensations.

c) All three aspects are therefore equally valuable and, most importantly, equally different from each other.

We say "most importantly", because some scholars (including Prof. V. M. Zhirmunsky in the preface to Walzel's book quoted above, p. 20) are inclined to place ( $\alpha$ ) in a separate group and contrast it with the other two as "content" opposed to "form", and thematic analysis opposed to formal analysis. Rejecting this division, we argue not against the terminology, but against the taxonomy which involves a dualistic view of literature and many unnecessary disputes.

We contend that $(\alpha)$ does not differ from either $(\beta)$ or $(\gamma)$ more than $(\beta)$ from $(\gamma)$, and that, therefore, the division into two groups, 1) $\alpha$ and 2) $\beta \gamma$, has no logical basis.

\section{§ 3. - The division of form according to real categories}

In accordance with the three specified types of stimuli, the study of literary form is divided into three parts.

I. Metrics (or, more precisely, "phonics"), i.e. the study of aesthetically used speech sounds, operates with a constant sound structure of words.

This includes:

a) The study of the relationship between speech sounds in length (metrics in the narrow sense), stress (tonics), and pitch (melodics).

\footnotetext{
* We are speaking of a constant sound structure of words, which is independent from the emotional colouring of pronunciation and which, e.g., in the Russian language, includes timbre, length, and pitch accent. These variable sound elements of words belong to the domain of declamation, which should be strictly differentiated from phonics. For more details, see the second part of the article "Granitsy nauchnogo literaturovedenija" ["The Limits of the Scientific Study of Literature"] (Iskusstvo [Art, 1927] III).
} 
b) Versology [stikhologija], i.e. the study of the structure of repetitive word combinations (feet, verse lines) and their boundaries (pause, caesura, the end of a line).

c) Strophics, i.e. the study of verse combinations [stikhosochetanija].

d) Euphonics, i.e. the study of qualitative sound repetitions (that is, of rhyme in the broad sense).

II. Stylistics operates with style, "i.e. the form of a word in its relation to meaning. Stylistics studies the use of all linguistic categories for aesthetic purposes:

a) Lexicology and semasiology (barbarisms, archaisms, provincialisms and so on as well as all tropes).

b) Phonetics in its relation to the meanings of words (annomination ${ }^{8}$, phonetic variation, homonymy, and other so-called phonetic figures, see $\$ 4 \mathrm{~b})$.*

c) Morphology (so-called grammatical figures, see $\$ 2$ ).

d) Syntax (see $\$ 2)$.

III. Iconology operates with images (see the definition in $\$[2]$ ) and their combinations, so that we distinguish, respectively:

a) images at rest: "the steed",

b) motifs, i.e. images in motion: "the steed broke its leg",

* Style is, of course, a problematic word because everyone uses it differently. For example, in [Richard] Müller-Freienfels book (Poetika [Poetics], tr. by [I. Ya.] K[ag]anov and [E. S.] Papernaya, Kharkov, 1923, p. 32), ${ }^{7}$ style includes omnia et quaedam alia [Latin: 'everything and something else']. We use the old terminology found in old textbooks of so-called "stylistics" as nevertheless the most understandable terminology, but would be grateful to anyone who could provide a more appropriate term. The old good word of our forefathers, "slog" [Russian: 'diction'] (as in "he speaks with excellent diction") would be the most acceptable if only an unambiguous adjective could be derived from it.

** An example of a purely phonetic variation:

Ty leti, leti sokolik vysokó i dalekó,

I vysóko i dalékko, priamo k drugu moemu.

[Russian: 'Fly, fly, my falcon, high and far,

And high and far, straight to my friend.]

A phonetic variation operates only on the condition of the logical consciousness of a complete equivalence of the meanings of both of its parts, and thus it retains its logical character. 
c) plots, i.e. the totality of logically related motifs of any literary whole: "The steed broke its leg; Christ healed the steed".

To these three disciplines we add a fourth: (IV) the study of combined composition, or simply composition, on which more later (see below $\$ \$ 8$ and 11).

\section{The relation of formal aspects to psychic intermediaries}

\section{§ 4. - Auxiliary intermediaries}

If the correlation we established between stimuli and intermediaries were absolute, it would be wrong. Absoluteness is a feature only of scholastic divisions. Organic divisions always allow intermediate types (species).

In fact, the different types of stimuli are not entirely covered by one main type of intermediary.

For example, all images operate by means of sensory associations, but these associations can be evoked not only by the meanings of words. On the other hand, stylistic phenomena always operate by means of logical acts, but are not limited to them.

We cite cases of this kind from all three fields.

a) Phonics. This includes cases when the sound itself evokes a sensory association regardless of the meaning of a word. We are certainly far from subjective speculations about "sound painting" [ $z v u k o p i s$ "], such as voyelles sombres ${ }^{9}$ denoting dark states of the soul, et cetera similia quae dicere pudet ${ }^{10}{ }^{* *}$

We are not speaking here of simple onomatopoeia, which belongs to the domain of linguistics. We are referring to particular and specific cases of onomatopoeia used aesthetically:

a) imitation of musical tempo. For example, in [Petr Ershov's] Konekgorbunok [The Little Humpbacked Horse], part III: “Ta-ra-rá-li, ta-ra-rá" etc., where the combinations of sounds themselves evoke the idea of the sound of the trumpet;

$\beta$ ) rendering of the duration of movements by a corresponding duration of verse lines or verse segments (see the endless examples in

\footnotetext{
* An example of a basic plot of the narrative part of a spell.

** Why should we not be at least as clever as linguists, who long ago abandoned the idea of finding any connection between the sound of a word and its meaning?
} 
Bücher's Rabota $i$ ritm [tr. by I. Ivanov, St. Petersburg, 1899, and Moscow, 1923], ${ }^{11}$ as well as in [Wilhelm] Uhl's Winileod [Teutonia 5], Leipzig, 1908). It is especially frequent in folk dance songs. Cf., for example, the brief alliterative verse segmentations to the beat of the Kamarinskaya ${ }^{12}$ :

Dáli dúlju Dár’je, dúre molodój.

Cf. also a German song sung in the process of piling - the short refrain corresponds to the short wham of a pile-driver:

Alle Mönsche mötte stärwe,

Rrum!

Blôt de döcke Siebert nöch;

Rrum!

Wer wart sîne Böckse ärwe?

Rrum!

So’ ne Noarsch hätt Keener nöch!

Rrum! ${ }^{13}$

b) Style. Here the auxiliary intermediaries accompany the main intermediary in the following cases:

a) in all the so-called phonetic figures, which are based on a repetition of words or parts of words, there appear sound repetitions inseparable from the figure itself, such as alliteration (e.g., in the case of paregmenon $^{14}$ ), rhyme (homoioteleuton ${ }^{15}$, epiphora ${ }^{16}$ ) or both ( symploce $^{17}$ ).

The semantic, logical aspect of stylistics remains unscathed.

Klika klika ne slykhala ${ }^{18}$ - antanaclasis ${ }^{19}$.

Edu, edu v chistom pole ${ }^{20}$ - epizeuxis ${ }^{21}$.

The phonetic device is the same, but the figures are different because one of them is based on the difference of meanings while the other on the identity of meanings.

$\beta$ ) Unusual lexical forms (barbarisms, archaisms, vulgarisms, etc.) can evoke associations with images depicting the milieu from which they came, and these associations may determine sensory perception. The phrase "A scrubby little man came in and said: 'That woman was not here" can be rewritten as "A scrubby little man came in and said: 'Dat woman wasn't here"', and the image of this man will become clearer. 
$\gamma$ ) We have already mentioned (see $\$ 2$ ) several figures which are not only capable of, but even prone to attracting images. We also pointed out that the essence of the "real" figuration is not the image, although the latter operates simultaneously with the figure.

It is clear that sounds and images attracted by stylistic figures are as such included in the phonics and iconics of a work and should be considered regardless of their origin, along with other sounds and images.

c) Iconology. Just as figures need concepts, and not images, in order to produce an effect (see $\$ 2$ ), so images can be linked to one another by means of only thematic devices, without the aid of any syntactic or lexical figures. Namely:

a) By contrast, without the mediation of an antithesis, oxymoron, irony or litotes. For example, Sigurd and Hagen in The Song of the Nibelungs or the countries of Lilliput and Brobdingnag in Gulliver's Travels.

$\beta$ ) By similarity or analogy, without the mediation of metaphors, comparisons, synonyms or parallelism. For example, the images of Grandmother and Vera in [Ivan Goncharov's novel] Obryv [The Precipice]. - This also includes all the so-called "parallel motifs", such as Lear's attitude to his daughters and Gloucester's attitude to his sons in King Lear.

$\gamma$ ) By causal relationship, without the aid of metonymy or an adverbial modifier of cause. Then we speak of "motivation" (some scholars use the term "internal motivation"): the reason for every misadventure of Odysseus is not indicated every time by a separate phrase, but we know that they are all motivated by Poseidon's wrath.

$\delta)$ By the correlation of quantity, volume or power, without the aid of synecdoche, comparison or hyperbolic epithets.

This includes hyperbole (which, by itself, is not a figure, but an iconological device). For example: "Do you know the church of Hagia Sophia in our city of Constantinople? You can climb for seven years, but you still won't reach the Crescent".22 Or: "Vois-tu cette mouche là-haut? - Non, mais je l'entends marcher!"23

Likewise, this includes a gradation of motives, such as in a fairy tale where the hero defeats first a lion, then a giant, and then a whole army.

In general, only individual images (e.g. "a white bird”) or simple motifs (e.g. "a white bird flies through the turquoise sky") are perceived through momentary associations, whereas plot-related composition [sjuzhetnaja kompozitsija] is 
usually perceived with the help of more or less complex logic acts, ${ }^{*}$ as was demonstrated above. But this is, of course, optional: descriptive poems are very often a collection of motifs related to one another only stylistically or even completely unrelated. One can even imagine a large work with minimal logical connection between images, such as the German symbolist [Paul] Scheerbart's [novel] Liwûna und Kaidôh.

\section{§ 5. - Number and time}

It is necessary to point out yet another important connection between the three types of form. Every individual formal element is perceived in an imperceptible moment. But if they are accumulated in a certain amount, then the categories of time and number come into force. What occurs is an act of recognition and comparison of the number of facts and the lengths of temporal periods as well as the comparison of facts by their arrangement in time.

These acts, while accompanying the perception of all more or less complex forms, are necessary intermediaries between them, [on the one hand], and the aesthetic emotion, [on the other], and are equally characteristic of all three groups of stimuli.

We shall see now that the aesthetics of number and time should by no means be ignored. We provide a few examples from all three fields.

a) Phonics.

a) The concept of number is in principle inseparable from phonic effects, which are all based on the repetition of sound phenomena. ${ }^{* * *}$ When we speak of a distich or tristich, we are referring to a known

\footnotetext{
* It is sufficient to compare an impression from a novel by Zola or Dostoevsky, which affects us by the correlation of a huge number of thematically linked plot-related images (characters and settings), with an impression from the dramas of the German [ex]pressionist [Fritz von] Unruh, who strike the reader with a multitude of images unrelated to the plot [vnesjuzhetnye obrazy] introduced by means of rhetorical figures, in order to understand the difference between the iconological and the stylistic binding of images.

** We are consciously simplifying the definition. The act of perception of time and quantity is, of course, much more complicated. But this definition is sufficient for the time being to outline the nature of literary forms and not lapse into unwanted digressions because, as was already said, we are first and foremost interested in literary forms, and not in psychic acts as such. We shall get a little closer to the question when analyzing individual examples.

*** In fact, we perceive the number only to a certain limit beyond which the concept of "many" begins and the awareness of a specific quantity disappears.
} 
quantity of strong breaks (marked or not marked by rhyme), altogether independently of the time span between them.

In other cases, the number of phenomena corresponds to a certain time duration, and therefore the comparison of quantities goes in parallel with the comparison of time fractions as in the case of the perception of isosyllabic and non-isosyllabic verse lines.

$\beta)$ We have purely temporal perception in metric poetry, ${ }^{24}$ e.g., in recognizing the equivalence of spondees and dactyls in [classical] hexameter.

$\gamma)$ Quite a few phenomena of versification are based on arrangement in time - including, among other things, the very concept of a "refrain".

b) Style.

a) A peculiarity of stylistic and iconological forms in contrast with phonic forms is that they are measured exclusively by the number of their parts, and not their duration.

Snorri Sturluson was already aware of this (Háttatal, ${ }^{25} 3$ ): "It is a [kenning] to call a battle a 'spear-clash', and it is tvikent (doubly modified) to call a sword 'fire of the spear-clash', and it is rekit (extended) if there are more elements [in the phrase]". ${ }^{26}$

When we speak of the brevity of expression achieved by the use of figures based on the omission of parts of a sentence (such as ellipsis ${ }^{27}$, asyndeton ${ }^{28}$ ), this brevity is not a temporal concept, but rather denotes the small number of parts in the expression. The two phrases:

"I came; I saw; I conquered"29

and "I arrived; I looked around; I gained victory"

- are stylistically equivalent but phonically different.

When we speak of the "long-windedness" of a story, we express a stylistic concept, because we speak of the disparity between the quantity of words or phrases (i.e. the syntactic structure) on the one hand and the quantity and importance of concepts on the other.

\footnotetext{
* This parallelism of temporal and quantitative perception allows us to significantly simplify in practice the process of analysis. Thus, in the study of syllabic verse, whose isochronism is very relative and whose isosyllabism is absolute, we can take no account of the former, and our study loses nothing by this.
} 
If we compare the style of a Russian futurist with the style of Gogol, in the latter we find all or nearly all the figures used by the former. It is clear that the futurist's style seems "pretentious" not because of the presence of these figures but rather thanks to their quantity. Therefore, a purely qualitative comparison of contemporary writers with the "classics" is for the most part unfruitful, since it does not reveal the true (in this case quantitative) character of the aesthetic effect.

$\beta$ ) At the same time, the recognition of the arrangement of stylistic units in time has tremendous significance. In particular, it is on this arrangement that many figures are based $\left(\operatorname{chiasmos}^{30}\right.$, isokolon ${ }^{31}$, hyperbaton ${ }^{32}$ ). It also determines the difference between anaphora and epiphora, ${ }^{33}$ symploce ${ }^{34}$ and anodiplosis ${ }^{35}$ etc.

c) Iconology.

a) It is obvious to anyone that the quantity of images in a given work is not irrelevant for its aesthetic perception. This is the basis for the difference between the social realist novel of [Émile] Zola (Les Rougon-Macquart), [Nikolai] Leskov (Nekuda [No Way Out]) or [Aleksandr] Amfiteatrov (Vos'midesjatniki [The Men of the Eighties]), which operates with a whole kaleidoscope of characters, and the psychological novel of [Stanisław] Przybyszewski (Homo Sapiens), [Peter] Nansen (Maria) or A[rnold] Bennett (Buried Alive), which focuses on the relationship between two or three personages.

$\beta$ ) The question of the arrangement of iconological elements in time is somewhat more complicated. Here we have to differentiate two distinct facts: real time and representation of time, imaginary time. The difference between narrative and descriptive literature (these notions are purely iconological) is based on the arrangement of motifs in this imaginary time: in narrative literature the motifs are assumed to be sequential, while in descriptive literature, they are strung together without any relation to time.

In real time the narrative motifs may be arranged in a completely different way. In the Aeneid, Aeneas's visit to Dido is narrated before the fall of Troy. ${ }^{36}$ Retrospection is an iconic device, which corresponds to hysteron proteron ${ }^{37}$ in stylistics, in the same way as contrasting images correspond to antithesis (see $\$ 4 \mathrm{c}$ ). 


\section{The relationships between the formal types}

\section{§ 6. - Independence}

All three types of form are in principle independent from each other. This independence manifests itself in the following ways.

a) Any of them may be missing in a given work, but the work remains artistic thanks to the other two. No one disputes the possibility of artistic prose (in the absence of metrical devices). In the stanza:

Die Nacht ist Kühl und es dunkelt,

Und ruhig fliesset der Rhein.

Der Gipfel des Berges funkelt

Im Abendsonnenschein. ${ }^{38}$

- stylistic art is kept to a minimum, but many generations have admired [these lines] for their imagery and harmony. A classic example of a poem with a negligible number of images is Pushkin's "Ja vas ljubil: ljubov' eshche, byt' mozhet..." ["I loved you; love has not yet, perhaps...", 1829]..$^{39}$ One may even imagine literary works that operate only by means of some type of form.

Everyone is familiar with futurist poems that consist of completely meaningless or almost meaningless sounds. This phenomenon occurs especially frequently in the refrain."

Such phrases as "Oh, have mercy, have mercy on me, sir, and treat with modesty of power the power of my modesty" ${ }^{41}$ (epizeuxis ${ }^{42}$ and antimetabole ${ }^{43}$ ) or "Decet, ut herilem filiam honorabiliter âmes et amabiliter honores"44 (antimetabole) - phrases that we call "empty rhetoric" - are nothing but pure stylistics.

We speak of "artless description" when it is made without rhetorical figures and operates using almost nothing but images. As is known, Tolstoy, in his novels, makes very little use of figuration and, while speaking in what is called "plain language", staggers us with his elaboration of images.

b) We can artificially alter any form without affecting others. It is sufficient, for example, to say:

* This includes meaningless sounds ("Mironton, mironton, mirontaine"), ${ }^{40}$ meaningless phrases (“Oj zhgi, zhgi, zhgi! govori, govori! Komariki, mukhi, komari-komari!' [Russian: 'Oh, burn, burn, burn! speak, speak! Mosquitoes, flies, gnats-gnats!']), and foreign refrains that make sense but are for the most part incomprehensible for the singer (the gypsy refrains of Russian romances, the Turkish refrains of Serbian songs, and so on). 
"I zvezdá so zvezdóju govorít"

[instead of "I zvezdá $s$ zvezdóju govorít"] ${ }^{45}$

- and the entire rhythmic scheme collapses, yet both the fantastic image of speaking stars and the figure of prosopopoeia ${ }^{46}$ remain firmly standing. This phenomenon always occurs when we deal with the translation of metric poetry into Russian ${ }^{47}$ as well as the prosaization of poems or the reverse (cf. Zhukovsky's "Undina" ${ }^{48}$ ). When we paraphrase, we change style but do not alter iconics. When we parodize and stylize, we often add new images to someone's turns of speech.

The independence and separability of form determine and justify the existence of three distinct historico-literary disciplines: metrics, stylistics, and iconology.

However, the study of a literary work as a whole should not be limited to separate inquiries in the three areas mentioned above because these areas often come into very close contact with each other and can (but do not have to) be in different types of relationship or dependence. We shall now try to delineate the said types and thereby determine the subject of our fourth discipline, "combined composition" (as opposed to metric, stylistic and iconic composition).

\section{§ 7. - Correlation}

We repeatedly see that one field of form in the course of its formation produces certain alterations in the adjacent field.

Thus, the abundant synonymy in Old Scandinavian poetry was called into being by phonics because [compulsory] alliteration demanded from the poet that he vary the beginning of words, i.e., in this case, roots. To express the same meaning, he tried to find semantically similar roots which then merged into a single meaning. On the contrary, when German poetry turned to rhyme $(\text { Otfried })^{49}$, it started to cultivate enallages ${ }^{50}$ of inflected endings for the sake of the final assonances.

The rhetorical prose of Ancient [Greece] is extremely instructive in this regard. Striving for the placement of identical grammatical forms at the end of rhetorical segments (homoioteleuton as a stylistic phenomenon) ${ }^{51}$ caused rhymes which subsequently became a self-sufficient euphonic device (free rhyme). This in turn produced a change in word order, thanks to which a correlation was established between this type of rhyme and [syntactic] inversion.

Every poet knows from experience how often a conceived image becomes transformed under the influence of rhyme. 
Attempts to define such influences of some types of form on other types can be fraught with considerable, sometimes insurmountable difficulties for the researcher, ${ }^{*}$ whereas it is mostly not at all sensed by the reader, ${ }^{* *}$ so that a huge number of correlations in poetry, as well as in nature, eludes us. Research in this domain is still scarce and highly desirable.

\section{§ 8. - Coordination}

The relationship between the formal groups is not, however, limited to the above. We have seen that the categories of number and arrangement are equally inherent in all three orders of formal phenomena. It is on these grounds (and only on these grounds) that the heterogeneous forms can be coordinated. For example:

Maráet òn edínym dúkhom líst,

Vnimáet òn privýchnym úkhom svíst.

* The difficulties will be partly eliminated if we restrict ourselves to the recognition of a number of permanently observed cases of coexistence without going into the question of any genetic relationship. However, this relationship may sometimes also be identified. Let us cite an example: the frequent use of phonetic figures (see $₫ 4 \mathrm{~b}$ ) often accompanies a particular system of sound repetitions [sozvuchija] (e.g., alliteration); the question of whether the figure was created for the sake of the sound (or vice versa, the sound repetition is an involuntary result of figuration) can be answered by counting the ratio of stylistically-related and free sound repetitions, etc.

** Sometimes correlations reveal themselves to the reader through a sudden and singular violation of a norm adopted in a given literary work for the sake of another norm, e.g. [violation] of the logical connection between an image placed at the end of a verse line and other images; then the reader speaks of words "brought in for rhyme's sake". And vice versa: a word that is indispensable from the thematic point of view violates the rhythm. This is how Captain Lebyadkin versifies [in Dostoevsky's The Devils]:

Mésto zánjal tarakán, Múkhi vozroptáli.

"Óchen’ pólon násh stakán", K Jupiteru zakricháli. ${ }^{52}$

No poká u nikh shól krík, Podoshól Nikífor, Blagoródnejshij starík...
[Russian:

'The cockroach occupied the place, and the flies started to grumble.

"Our glass is too full", They cried out to Jupiter. But while they were shouting, There came along Nikifor, A very noble old man...']

The inability to find a suitable rhyme for "Nikifor" prevents the Captain from finishing the poem and makes him disrupt the tetrastich basis of the stanza. The newest Captain Lebyadkins call this "a device laid bare" ["obnazhennyj prijom"]. 
[Russian: 'He scribbles on a sheet of paper in one breath,

He hearkens to the whistle with an unattentive ear.' $]^{53}$

There are as many rhyming endings here as there are parallel parts of the sentence, and they are arranged in the same sequence, i.e. the phonic and stylistic elements are coordinated on the basis of the categories of number and arrangement.

The specific problem of the coordination of figures of repetition with phonics and iconology is discussed in Prof. V. M. Zhirmunsky's book titled Kompozitsija liricheskikh stikhotvorenij [Composition of lyrical poems] ( $\mathrm{P}$ [etersburg], 1921), in which the reader can find abundant examples of such phenomena.

Of course, not only these figures can be matched with images and strophes. Many poems are composed in the form of a simile (e.g. "Les colombes" by Sully Prudhomme) ${ }^{54}$ or in the form of an antithesis (e.g. the first poem from Petronius's Satyricon, in which the two parts of an antithesis are expressed by two different metres). Many Russian chastush $k^{i 5}$ and other short texts are based on parallelism.

Coordination of stylistic forms with iconic forms is also found in largecaliber works. An example may be Anatole France's novel Les dieux ont soif [The Gods Are Athirst], where the author concludes the descriptions of the Terror and the Directory with two identical love scenes, which are designed

* Isokolon: $\quad$ a) Skol'ko lesa ne rubila, krepche duba ne nashla.

b) Skol'ko parnej ne ljubila, luchshe Vani ne nashla.

[Russian: 'No matter how many trees I've hewn, I didn't find one stronger than the oak. No matter how many guys I've loved, I didn't find one better than Ivan']

Simile: $\quad$ a) Tiene la Virgen del Carmen

Un escapulario al cuello

b) Y yo también tengo otro

Con tu retratito dentro. ${ }^{56}$

[Spanish: 'Our Lady of Mount Carmel wears a scapular on her neck, And I also wear another with your portrait inside'.]

Oxymoron: a) Tishe jedesh',

b) Dal'she budesh'.

[Russian: 'The quieter you go, the farther you'll get'.]

Antithesis: a) Srbin pije - bekrija je.

b) Turčin puši - budala je.

[Serbian: 'The Serb who drinks is a drinker.

The Turk who smokes is a fool'.] 
to demonstrate the independence of intimate human passions from social upheavals. Anatole France coordinates this "iconic epiphora" with a genuine epiphora by ending both love scenes with the same words of the female character.

The study of such a kind of combined composition as distinct from plot composition or phonic composition, i.e., of the correlation and coordination between heterogeneous forms, is the subject of the fourth discipline of literary theory, the least developed of all.

It should be noted, however, that in the total mass of literary material, coordination is not a universal phenomenon and in the vast majority of cases the formal types operate without any apparent relation to each other.

\section{§9. - Commensurability}

The study of the relationship between types draws its method from the material itself. We have already said that types are united by the concepts of number and arrangement. These concepts also establish the feature of commensurability between the three types. Such issues as the imagery of a literary work or its rhetoricity as well as the ratio of logical pauses and rhymes can be solved only by means of quantitative analysis, which, along with comparisons of the arrangement schemes of literary works, will eventually become the main instrument of studying composition.*

\section{$\S 10$. - The conception of a literary work}

We define the conception of a literary work in the same way as [Bernhard] ten Brink ([Über] die Aufgabe der Literaturgeschichte, Strassb [urg] 1891, p. 18[1]9): "Da übt denn der Dichter sein recht die Fabel seinem Zwecke gemäss, d. h. in Übereinstimmung mit seiner Idee umzugestalten. Diese Idee ist aber schliesslich nichts anderes als die Art, wie er den Sinn seiner Fabel fasst... Die Frage ob tragisch oder komisch, ob idyllisch, [elegisch] oder satyrisch, wird... bei der Konzeption... entschieden". [German: 'Thus the poet exercises his right

\footnotetext{
* We find the same device in Zola’s La Débâcle [The Downfall]: the motif of a farmer calmly plowing the field.

** In this article, where we discuss the foundations and not the methods of formal analysis, we must confine ourselves to this brief remark in the hope of being able to dwell on these important points somewhere else.
} 
to transform the story according to his purpose, i.e., in accordance with his idea. But this idea is, after all, nothing but the way in which he expresses the meaning of his story... The question of the tragic or comic, the idyllic, elegiac or satiric, is... resolved ... by the conception.]

Although we agree with ten Brink in essence, we are nonetheless inclined to amend this formulation.

The conception of a literary work is an idea or a representation of the emotions that are essential for the binding of plot-related elements [sjuzhetoobrazujushchie elementy]. In the former case we are dealing with ideological concepts, in the latter, with emotional concepts (anger - diatribe ${ }^{57}$, sadness elegy, cheerfulness - humor, and so forth). We are not going to get into particulars concerning the nature of conception. What has already been said is sufficient to determine its relationship to the formal types.*

a) Iconic forms are the only forms capable of illustrating an idea and evoking emotions on their own, but this capability is very limited.

Separate images are neutral in principle, there are no specifically comic, tragic, or religious images. Blok's Pierrot is a profoundly tragic character. ${ }^{58}$ Associations with a particular emotion can only be evoked by a combination of images related to each other in a certain way by means of plot-related composition. The "dragon" in the Middle High German epic is terrible because it threatens the hero with death, but in Rideamus's parody (Hugdietrich) the "dragon" is ridiculous ("der Drache war total besoffen" [German: "The dragon was totally drunk'])..$^{59}$

But even here, with complex combinations of motifs, the connection between the plot and the emotional conception is very unstable and, most importantly, short-lived.

The tomcat Murr believed that when a person is credited with "not having invented gunpowder" this commends his meekness, thereby mistaking satire for a panegyric. ${ }^{60} \mathrm{~A}$ medieval scholar considered the Song of Songs a work of profound mysticism, whereas a present-day scholar would tend to interpret it as an epithalamium ${ }^{61}$. Which one of them is a tomcat Murr after all?

b) Stylistic forms are neutral to an even larger extent. Neither parallelism nor simile serves particular ideas, but they can be used to express any ideological conception. As regards the emotional concepts, the possibilities of connecting the conception and the style are very limited.

\footnotetext{
* The conception of a literary work will be discussed further in the continuation of our article on "the limits of the scientific study of literature" forthcoming in the next issue of Iskusstvo [Art] (publication of the State Academy of Artistic Sciences).
} 
a) The style of a word (lexicon) includes forms capable of eliciting associations that complement the concept being expressed (see $\$ 4 \mathrm{~b}$ ). It is commonly accepted to speak of the emotional colouring of archaisms, provincialisms, or vulgarisms. But it would be much better to speak of an associative potentiality. A vulgarism as such is not connected to any emotion: it is neither ridiculous, nor disgusting, nor tragic, nor idyllic. It acquires such characteristics only in conjunction with a corresponding image or a complex thereof. In the phrase "der Drache war total besoffen", a burschikoser Ausdruck ${ }^{62}$ is not comic in itself, but it evokes an idea of the milieu in which it is normally used. Such a milieu is very distant from the range of concepts from which the concept of a dragon is taken. It is the unexpected abnormal combination of these two concepts that causes laughter.

$\beta$ ) There are many so-called emotional figures, i.e. those that lend to speech a quality as if it were pronounced by a very excited person. These include exclamations, erotema (the rhetorical question) ${ }^{63}$, dialogism $^{64}$, ellipsis ${ }^{65}$ and so on.

However, these figures are not capable of unequivocally depicting the emotion that they expressed. The rhetorical question may as well serve admiration and indignation, i.e. both panegyric ${ }^{66}$ and diatribe ${ }^{67}$ :

Is he not a great man?

Is he not the most despicable of mortals?

Therefore, here the stylistic forms also preserve their modal character: they only emphasize the emotional conception without defining it.

c) Phonic forms are absolutely incapable of evoking an association with any emotion independently [of other forms]. They can focus the listener's attention on this point only when accumulated in large quantities at the moment of peak emotional stress produced by the images [in a literary work].

In the humorous Serbian folk song about a sparrow, "Vrabac-pipac" "The Little Sparrow Bird"), onomatopoeia enhances the comic effect of the punchline:

[Serbian:

...Da mi starac štap da,

Da isteram vrapca

Pipca

Iz bobca.

'.to make the old man give me a stick

to drive away the sparrow,

the little bird,

from the beans.' ${ }^{67}$ 
Therefore, in the vast majority of cases, the emotional potential of style and metrics only covers up the simultaneity of their actions with the action of the plot combinations which evoke emotional association.

Thus, the study of the conception of a literary work as one of the features of thematic composition is entirely included in iconology. But the great bulk of formal elements (including images) remain completely neutral with respect to the basic conception.

We often hear the assertion that a literary work is a whole whose every part serves to express a central concept (or, as some say, the main "idea"). This is an arbitrary judgment that has never by any stretch of the imagination been proven to be true. In such cases, it is common to speak of the impotence or inexactness of scientific methods. I suppose, however, that the more exact our methods become, the more difficult it will be to use them to prove assumptions that are fundamentally incorrect and based solely on a one-sided interpretation of the unity of impression produced by a literary whole.

\section{$\S 11 .-$ The unity of impression}

Thus, we now come right up against the question of the unity of artistic impression. In order to understand the nature of this unity, we need only to draw conclusions from what was already stated above.

It is clear that there can be no qualitative harmony between the individual fields of form. Unity [of impression] is created by the following factors:

a) The simultaneity [of different effects], as in the cases described in $\$ 4$ and $\$ 10$.

b) The similarity in their order in the cases of arrangement coordination (see $₫ 8) . *$

c) Their quantitative coincidence in the cases of numerical coordination (see $₫ 8$ ).

d) Their rapid alternation. Categories (a), (b), and (c) embrace only a very limited number of facts. In the great majority of cases, as was argued in $\$ 8$, formal types operate without any relation to each other. Quickly alternating and replacing each other, they do not give the perceiver enough time to identify the nature of the stimulus. This leads

\footnotetext{
* We place this phenomenon in a separate category because it does not always require complete simultaneity. This can be illustrated by the example from Anatole France cited in $₫ 8$, in which the unity of the final scene begins to affect us long before we get to the second part of the epiphora.
} 
to a characteristic confusion of impressions, as a result of which the perceiver starts to believe that the sounds themselves depict "the silence of the landscape", and the like.

The task of the researcher is to make some sense out of this whirlpool of impressions and classify them to determine their quantitative and temporal relationship as well as possible.

These are the foundations of formal analysis that earn it citizenship rights in the sciences. The productivity of formal analysis is equal to that of a naturalist, of whom nobody would demand that, having dissected a bird into its constituent elements, he should recreate exactly the same bird from them. No one should demand this from us either. Moreover, in literary studies synthesis is impossible without preliminary analysis. However, the arguments in support of this statement as well as all the issues related to formal synthesis are, of course, beyond the scope of this article.

\section{Translators' notes}

1 This article was first published in Russian as 'Prostejshie osnovanija formal'nogo analiza' in: Ars poetica I. Moskva: Izdanie GAKhN, 1927, pp. 7-28. Translation by Michael Lavery and Igor Pilshchikov. The translators' additions (such as full names, translations of titles etc.) and corrections of obvious errors are enclosed in square brackets. The footnotes marked by asterisks are Yarkho's own notes; the endnotes marked by Arabic numerals are added by the translators.

2 A translation of Oskar Walzel's Die kunstlerische Form des Dichtwerks. Berlin: E. S. Mittler und Sohn, 1919.

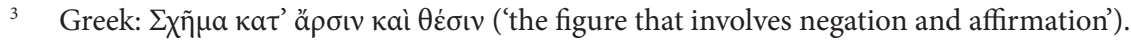

4 Greek: $\dot{\varepsilon} v \alpha \lambda \lambda \alpha \gamma \eta$ ' ('interchange'), the use of one grammatical form in place of another.

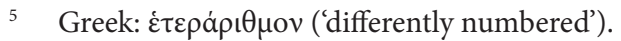

6 Latin: 'made almost equal'.

7 A translation of Müller-Freienfels's Poetik. Leipzig, 1914¹, $1921^{2}$.

8 Same as adnomination and agnomination (paronomasia), the juxtaposition of words which sound similar.

9 French: 'dark vowels'.

10 Latin: 'and other similar things one is ashamed to speak of'.

11 A translation of Karl Bücher's Arbeit und Rhythmus. Leipzig: B. G. Teubner, 1896', $1899^{2}$.

12 A traditional Russian folk dance.

13 From Karl Reuschel's Die deutschen Weltgerichtsspiele des Mittelalters und der Reformationszeit (Teutonia 4). Leipzig: E. Avenarius, 1906, S. 222.

14 Greek: $\pi \alpha \rho \eta \gamma \mu \varepsilon$ vov ('derived'), the juxtaposition of words with the same root.

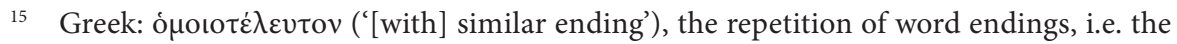


juxtaposition of words with similar endings. Same as homeoteleuton.

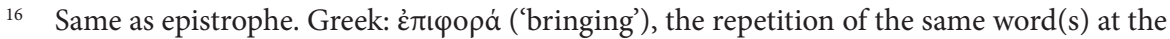
end of successive phrases or sentences.

17 Greek: $\sigma \nu \mu \pi \lambda$ ок' ('entanglement'), the combination of epiphora and anaphora, i.e. the repetition of the same word(s) at the beginning of successive phrases or sentences.

18 Russian: 'The company [klika] did not hear the shout [klika, Gen. sing. of klik]'. Source unknown.

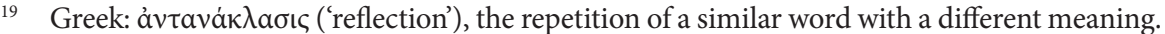

20 Russian: ' $[\mathrm{I} \mathrm{am}]$ riding, riding in the open field'. From Aleksandr Pushkin's "Besy" ("The Devils", 1830).

${ }^{21}$ Greek: $\dot{\varepsilon} \pi i \zeta \varepsilon v \xi ı \varsigma$ ('fastened together'), the repetition of a word or phrase in immediate succession.

22 Source unknown.

23 French: 'Can you see that fly there? - No, but I can hear it walking'. An anecdote about a Gascon already known to Laurent Bordelon and Pitaval (see Heures perduës et divertissantes $d u$ Chevalier de [Bordelon]. Amsterdam, 1716, p. 141; Bibliothèque des Gens de Cour, ou Mélange curieux des bons Mots... Ed. by [François] Gayot de Pitaval. Paris, 1723, vol. 1, p. 257). In a form of a short dialogue it can be found, for example, in A[ugustin] Gazier, Traité d'explication française, ou Méthode pour expliquer littéralement les auteurs français. Paris: E. Belin, 1880 ${ }^{1}$ $\left(1900^{7}\right)$, p. 188.

24 See note 47 below.

25 Old Norse: 'A list of verse-forms; a catalog of metres' (the fourth part of the Edda).

26 Translation, with modifications, from: Snorri Sturluson, Edda (Everyman's library). Translated and edited by Anthony Faulkes. London: J. M. Dent; Rutland, Vermont: Ch. E. Tuttle, 1995, p. 168.

27 Greek: $\varepsilon \hat{\lambda} \lambda \lambda \varepsilon ı$ เ५ ('omission'), the omission of one or several words from a phrase or clause.

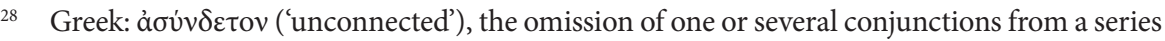
of related clauses.

29 Latin: "Veni, vidi, vici" (a phrase attributed to Julius Caesar).

30 Greek: $\chi ı \alpha \sigma \mu$ ó ('likened to the letter X'), the figure of speech in which the elements of the first clause are used in the second clause but in inverted order. Same as chiasmus.

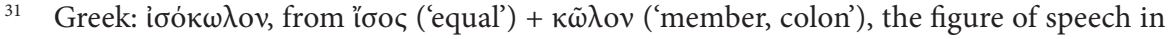
which the cola are equal in structure, as in "Veni, vidi, vici".

32 Greek: vंז̇́ $\beta \beta a \tau o v$ ('transposition'), a transposition of words, syntactic inversion.

33 See notes 16 and 17.

34 See note 17.

35 Greek: å $v \alpha \delta i \pi \lambda \omega \sigma \iota \varsigma$ ('doubling'), the repetition of the last word of a preceding clause or sentence at the beginning of the next clause or sentence.

36 Compare Viktor Shklovsky's dichotomy of fabula (story) and sujet / sjuzhet (plot).

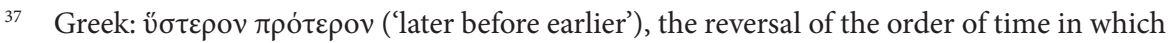
events occurred, placing the more important later event before the less important earlier event.

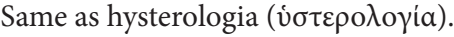


38 German: 'The night is cool and it darkens, / and calmly flows the Rhine. / The peak of the mountain sparkles / in evening sunshine'. A slightly modified quotation from Heinrich Heine's "Die Lore-Ley" ("Ich weiß nicht, was soll es bedeuten", 1822).

39 Compare the analysis of Pushkin's "Ja vas ljubil" in Section II ("Poetry without images") of Roman Jakobson's later article "Poetry of grammar and grammar of poetry" (1960).

40 The refrain of the French folk song "Marlbrough s'en va-t-en guerre".

41 Source unknown.

42 See note 21.

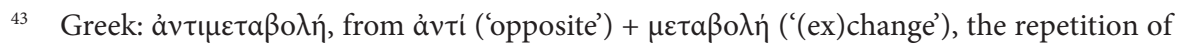
words in successive clauses, but in inverted order (as in "poetry of grammar and grammar of poetry").

44 Latin: 'You should love your lord's daughter honourably, and honour her lovingly'. Hrotsvitha of Gandersheim, Gallicanus (I, 1). Translation, with a modification, from The Plays of Hrotswitha of Gandersheim, Bilingual edition. Translated by Larissa Bonfante. Edited by Robert Chipok. Mundelein, Ill.: Bolchazy-Carducci, 2013, p. 15.

45 Russian: 'And star speaks with star'. From Mikhail Lermontov's "Vykhozhu odin ja na dorogu..." ("All alone along the road I am walking...", 1841), a classic example of Russian trochaic pentameter. By replacing the preposition $s$ ('with') with its vocalized version so, Yarkho intentionally violates the metre of this line.

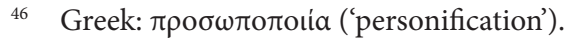

47 Metric poetry: same as quantitative poetry (quantitative verse). Russian translations use accentual analogues of quantitative metres.

48 Vasily Zhukovsky's poetic translation (1831-1836) of Friedrich de la Motte Fouqués prose tale "Undine".

49 Otfried of Weissenburg (9th century), the oldest German poet known by name, author of the Evangelienbuch, a rhymed version of the Gospels.

50 See note 4.

51 See note 15

52 Yarkho marks the word Jupiteru because it violates the trochaic metre of the poem.

53 From Pushkin's "Istorija stikhotvortsa" (“The Story of a Poet", 1817-1818).

54 Yarkho confuses here two different poems, Sully Prudhomme's "La colombe et le lis" (1869) and Théophile Gautier's "Les colombes" (1838). Yarkho likely had in mind the latter (which employs a number of similes) rather than the former (structured around an extended metaphor).

55 A chastushka (plural: chastushki) is a humorous Russian folk song.

56 A Spanish folk song. From Gorjeos del alma: Cantares populares, Coleccionados por Ramón Caballero (Biblioteca Universal 97). Madrid: Imp. de la Biblioteca Universal, 1884, p. 97.

57 See note 67 below.

58 Pierrot, a stock character of commedia dell'arte, is a tragic personage in Aleksandr Blok's play Balaganchik (The Fairground Booth, 1906).

59 From Hugdietrichs Brautfahrt: Eine romantische Liebesgeschichte in sieben Gesängen (Hugdietrich's Honeymoon: A romantic love story in seven cantos, 1907) by Rideamus (a pen-name 
of Fritz Oliven).

60 Tomcat Murr, the main character in E. T. A. Hoffmann's satirical novel Lebens-Ansichten des Katers Murr (The Life and Opinions of the Tomcat Murr, 1819-1821), misunderstood the German saying "Er hat das Pulver nicht erfunden", which literally translates as 'he did not invent gunpowder' but actually means 'he did not have much success in life'.

${ }^{61}$ A wedding song sung at the door of the nuptial chamber.

62 German: 'an impudent (literally: student-like) expression'.

63 Greek: غ̇ $\rho \dot{\tau} \tau \eta \mu \alpha$ ('question').

64 An imaginary dialogue. Not to be confused with the Bakhtinian concept of dialogism.

65 Greek: é $\lambda \lambda \lambda \varepsilon \iota \psi \iota \varsigma$ ('deficiency'), the omission of a word or phrase.

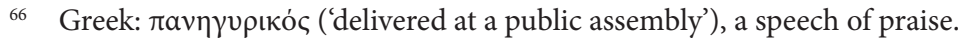

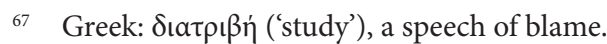

68 A cumulative song of the "This is the house that Jack built" type, from Srpske narodne pjesme, skupio ih Vuk Stefanović Karadžić. Knjiga 5, u kojoj su različne ženske pjesme. Državno izdanje. Beograd: Državna štamparija Kraljevine Srbije, 1898, p. 473-476 (no. 631). 